\title{
A SPANISH OBJECT-LESSON IN CODE-MAKING
}

The nineteenth century bids fair to be remembered as the age of codification (or rather re-codification) of the Civil Law. Commencing in 1804 with the Napoleonic Civil Code, which, it is increasingly apparent, affords the most enduring monument to the genius of the ill-fated Corsican, the century closed with a parallel achievement in the prcmulgation of the Code which marked the unification of substantive law for the German Empire. Between these two great landmarks appeared other codes of lesser fame-such as that of Bogisic the liw-giver of Montenegro-and one which, though little known to American lawyers, and still less to American legislators, may yet exercise a stronger influence upon American jurisprudence than any of its contemporaries.

\section{HisToRY.}

The Código Cizil is the late ripening flower of Spanish juridical evolution.- By a strange coincidence this product of Hispanic genius appeared in the centennial year of the French Revolution and of the events that mark the first practical workings of the great land-mark of American public law-the Federal Constitution. But the code formally promulgated in $188 \mathrm{~g}$ was the out-come of a movement begun more than three-quarters of a century previous and stimulated by still earlier efforts at codification on the part of Spanish jurists. With the possible exception of Italy no nation indeed has an ampler juridical background. But Spanish codification preceded Italian, for the earliest Spanish Code (Siete Partidas) based largely on the law of Rome, appeared soon after the middle of the thirteenth century, while in Italy the revived study of the Roman law had begun only with Irnerius at Bologna in the century preceding. Other codes of superior merit were produced in Spain from time to time, such as the Ordenamiento de Alcald in 1348, and the Leyes de Toro of 1505 .

Legal Chaos in Spain.

But the defect of these codes as of the Spanish legal systems generally, was lack of universality. The ancient petty kingdoms which were gradually merged into the Spanish monarchy 
retained, for the most part, each its own system of laws. A Code of Castile, however excellent in form and contents, might have no force in Catalonia. Indeed at and prior to the beginning of the nineteenth century no less than six diverse juridical systems prevailed in various parts of Spain and the result, in the language of the learned Spanish jurist, Sánchez Román, ${ }^{1}$ was "the most anarchical multiplicity, the greatest lack of harmony with historic reality, vagueness, uncertainty and the most complete chaos."

It is clear that this condition presented a problem more serious even than that which confronted the French law reformers of the first national assembly, or those who framed the Code Napoleon fifteen years later. The diversity and confusion in the law of pre-revolutionary France was great, but not so great as that of Spain at the corresponding period. Besides the Spaniards are a more conservative people and the different regions of the peninsula cling more tenaciously to their peculiar "fueros" and customs.

\section{The American Analogy.}

The situation was rather more analogous to that which prevails to-day in the states of the American Union. Except in Louisiana we have as the basis of our jurisprudence the English common law. But the whole tendency of our federal system, with the increase in the number of states, in legal theory sovereign and foreign to each other, has been toward juridical diversity. A legislature, supreme in its own sphere, sending forth new statutes year after year-a court of last resort, independent of every other, constantly making new precedents with the force of law-such are the forces at work in each of our nearly half a hundred states to develop a system of jurisprudence of its own. Even our law schools accelerate this tendency, for each naturally lays particular stress on the law of the state of its location. If not already so, will not the words of the Spanish jurist above quoted soon be applicable to the condition of our American law? No active practitioner any longer attempts to keep abreast of the jurisprudence of any state but his own. In entering the courts of another he is on ground almost as strange as if he were practicing in a foreign country.

It is of course not merely or mainly the professional class that suffers from this condition. In these days of enterprises

I. Estudios de Derecho Civil (Studies in Civil Law), Madrid, I8go, p. 500 . 
conducted on a national and even international scale, it is the business interests which must ultimately feel most keenly the inconvenience of subjection to fifty diverse juridical systems in one country. Hence the inspiration of such efforts as that toward the adoption of a uniform statute on negotiable instruments which is nothing more or less than a movement for the codification of one branch of the commercial law. Is it not worth while in this connection to follow the course of another nation, which under somewhat similar conditions, has codified not alone its commercial, but its entire body of law?

The Modern Code Movement.

It was this chaotic condition of her jurisprudence that hung like an incubus over Spain in the opening years of the nineteenth century. In that period, as the author already quoted observes, began "a series of events, of diverse character, realized under distinct initiative and with variety of result, but all inspired and caused by a single thought-the codification of our civil law." The movement found clear expression in the Cadiz Constitution of 1812, the instrument which marks the real beginning of Spain's modern constitutional history. That instrument, voicing aspiration rather than announcing actuality, declared: " $u n$ solo Código Civil regird en todos los dominios de la monarquia española" (one civil code only shall be in force throughout the dominions of the Spanish monarchy). The same Cortes which framed the constitution adopted, as early as February, I8Ix, a proposal presented by the deputy Espiga y Gadea, for undertaking as soon as practicable the codification of the Spanish law in all important branches including civil, penal and remedial. In 1813 the Code Commission composed of five distinguished Spaniards was appointed by the same body, but the reaction of the following year prevented any real results, and a second commission named in $182 \mathrm{r}$, met a similar fate. The movement now passed for a time from official into private hands and several drafts or projects appeared from time to time, one being presented to the Cortes in 1839 . In 1843 a royal decree was issued naming a General Code Commission of twenty-four under which the work of codification was well started, but which was succeeded three years later by a smaller commission which completed its labors in the form of a draft of a Civil Code in $185 \mathrm{r}$.

The instrument thus framed after forty years of effort marks an epoch in the history of Spanish jurisprudence. While open to criticism in respect to classification and terminology, it con- 
tained many new features borrowed from foreign sources, and showed that its framers were diligent students of comparative legislation. Not only did they make use of the jurisconsults and commentators, but the Code Napoleon supplied many ideas, like the institution of the family council, which were thus introduced into Spanish law for the first time. But the new project also in some features followed closely the law of Castile and this was one of the causes of opposition. Partly by reason of this and partly because the country was not yet ready for the great reform, the project of $185 x$, like its predecessors, was to remain unrealized in its existing form.

\section{Realization.}

In the period which followed, the reformers devoted themselves to the codification of specific branches of the law, such as the mortgage law, the notarial law, the law of waters, etc., much as our law reformers are now attempting to secure the enactment of a uniform statute governing divorce and another pertaining to negotiable instruments. This kept alive interest in the subject and paved the way for greater results. Finally in $\mathrm{r} 880$ a Royal decree was issued providing for a general codification of the Spanish law on the basis of the draft of 1851 , and naming a commission of eminent jurists to undertake the task. Two circumstances, both highly suggestive, now favored the successful consummation of the movement. In the first place each member of the commission was chosen from one of the several regions into which the peninsula was juridically divided. This favored the selection of the best features of each, tended to prevent the undue preponderance of any, and encouraged the harmonizing of differences. Another aid was the calling of juridical congresses in these different regions and the consideration by them of those features of the local law which most deserved incorporation into a national code. Such congresses were held at Saragossa in $\mathbf{r 8 8 0}$, at Madrid in 1886 and at Barcelona in 1888 , and the programs, practical and yet scientific, were highly instructive and helpful. Opposition had not disappeared and the exigencies of Spanish politics tended to delay the consummation. But in 1885 the distinguished jurist Silvela was Minister of Grace and Justice and he obtained the authority of the Cortes to publish a Civil Code framed on a new basis, but utilizing the work of previous years. This project, after exhaustive discussion and approval by both chambers of the Cortes, received the royal assent on May II, r888, and became 
substantially the law of all Spain on May 1, 1889, exactly nine years before the tragic battle of Manilla Bay. ${ }^{2}$ On July $3 x$, the new Code was extended to Cuba, Puerto Rico and the Philippines where, with some slight modifications, it has ever since remained in force. Strange irony of fate that led the Spanish lawmakers to legislate so minutely and elaborately for the Colonies which they were so soon to lose! Fortunate event which gave to each of these regions, on the eve of a new and then unexpocted career, a system of laws fitted to conditions both old and new, yet embodying the best results of juridical experience and scientific thought!

Character of the Code.

Of. the instrument brought into existence by this long and laborious process only a brief and inadequate mention is permissible here. Its real and historic basis, even more than that of the Siete Partidas, is the Roman law of the Golden Age and it comprehends the subjects of Persons, Property and Obligations in the same order and with much the same phraseology as the Institutes of Justinian. The subject of the fourth book of the Institutes, relating to actions, is rightly omitted, however, because as a Código Civil this instrument includes only private substantive law, or that which treats of the rights and obligations of individuals inter se, and is not concerned with remedial law, including actions, which deals with the methods of enforcing such rights and duties.

Doubtless the Spanish codifiers profited much from the Code Napoleon, but we have it on the authority of the eminent French jurist Leve, that the Spanish Code is the superior. When it first came to the attention of critical American judges and lawyers in our new possessions they were amazed at its comprehensiveness and completeness-charmed with its clearness, conciseness and simplicity. They, who were wont to engage in the tedious and reason stifling process of pursuing, through the maze of precedent, with the lame assistance of cumbrous digests, voluminous treatises and multitudinous reports, some fine point in the law of Contracts or Real Property, found in this brief Spanish Code, smaller than almost the least of American text books, a logically arranged group of principles from which the law applicable to a given case could be deduced rationally and with little difficulty. Coming at an epoch when business inter-

2. In Catalonia and Aragon its force is still somewhat qualified; in a fer other provinces the old fueros still remain. 
ests as well as the legal profession are beginning to demand relief from

$$
\begin{aligned}
& \text { "The lawless science of our law } \\
& \text { The Codeless myriad of precedent," }
\end{aligned}
$$

this discovery of the achievement of the hitherto unappreciated Spaniard is most timely and serviceable. It is one of the farreaching consequences of the Spanish-American war which was never foreseen and is even now little suspected. Much has been said and rightly of the improvements of the courts of our insular possessions through the introduction of the simpler and more practical American system of procedure. The benefits will not be altogether one-sided if through this contact of legal systems the American people shall learn the merits of the Spanish Codigo Civil and from it the feasibility and gain of codifying their private substantive law.

$$
\text { Charles Sumner Lobingier, Ph.D., LL.M., }
$$

U. S. Judge of 'the Court of First Instance, Philippine Islands. 